\title{
VARIASI JUMLAH LUBANG DAN UKURAN DIAMETER BURNER KOMPOR PREMIUM TERHADAP KONSUMSI BAHAN BAKAR
}

\author{
Kemas Ridhuan ${ }^{1}$, Ervan Septa Darma² \\ Jurusan Teknik Mesin Universitas Muhammadiyah Metro ${ }^{1,2}$ \\ Jl. Ki Hajar Dewantara 15 A Kota Metro \\ Email : kmsridhuan@yahoo.co.id, ervanseptadarma123@yahoo.com
}

\begin{abstract}
Abstrak
Komsumsi bahan bakar pada suatu kompor sangat dipengaruhi oleh beberapa hal diantaranya burnernya, khususnya ukuran diameter lubang barner dan jumlah lubangnya. Pada kompor dengan bahan bakar premium tentu ini akan berbeda hasil pembakarannya, seperti nyala api, waktu, temperatur dan jumlah panas yang dihasilkan. Tujuan dari penelitian ini adalah untuk mengetahui variasi jumlah lubang dan diameter burner kompor terhadap konsumsi bahan bakar premium dan jumlah panas yang di hasilkan. Metode penelitian ini yaitu dengan memvariasikan diameter burner 5 , dan $6,5 \mathrm{~cm}$, dengan jumlah lubang burner 16,18 dan 20 buah. Ukuran diameter lubang burner $2 \mathrm{~mm}$, tingi burner $44 \mathrm{~mm}$, dan bahan bakar mengunakan premium. Diuji dengan memanaskan air. Hasil penelitian menunjukkan bahwa untuk diameter burner $5 \mathrm{~cm}$ dengan jumlah lubang 16 menghabiskan bahan bakar $160 \mathrm{ml}$, memiliki jumlah panas 1331,3 kJ. Pada jumlah lubang 18 menghabiskan bahan bakar $130 \mathrm{ml}$, dengan jumlah panas yaitu sebesar 1435,8 kJ. Pada jumlah lubang 20 menghabiskan bahan bakar $120 \mathrm{ml}$. dengan jumlah panas $1414,9 \mathrm{~kJ}$. Sedangkan untuk diameter burner 6,5 cm pada jumlah lubang 16 menghabiskan bahan bakar $120 \mathrm{ml}$ dengan jumlah panas 996,9 kJ. Jumlah lubang 18 menghabiskan bahan bakar $100 \mathrm{ml}$, dengan jumlah panas 1080,5 kJ. Pada jumlah lubang 20, sisa bahan bakar $80 \mathrm{ml}$, dengan jumlah panas $1128,6 \mathrm{~kJ}$.
\end{abstract}

Kata Kunci : bahan bakar, premium, burner, lubang, diameter.

\section{PENDAHULUAN}

Pemenuhan kebutuhan gas LPG untuk nasional tersebut sebenarnya belum dapat disediakan sepenuhnya oleh pemerintah. Hal ini disebabkan karena permintaan terhadap gas LPG yang lebih besar dari jumlah penawaranya. Sehinga pemerintah masih harus melakukan inpor gas LPG untuk memenuhi kebutuhan LPG nasional tersebut dan untuk tabung gas LPG ukuran $3 \quad \mathrm{~kg} \quad$ yg masih di subsidi pemerintah, untuk saat ini mencapai harga
Rp 22.000,00. Namun untuk harga bahan bakar premium untuk tahun ini mengalami penurunan menjadi $\mathrm{Rp} 6.450,00 /$ liter.

Premium adalah sebuah cairan yang berasal dari minyak bumi dan sebagian besar tersusun dari hidrokarbon serta digunakan untuk bahan bakar pada mesin pembakaran dalam. Karena terdiri dari berbagai macam campuran bahan, premium memiliki daya bakar berbeda - beda menurut komposisinya. Ukuran daya 
premium dapat dilihat pada bilangan oktan yang terdapat pada setiap campuran.

Burner merupakan suatu alat yang penting di dalam suatu kompor karena fungsi dari burner adalah tempat dimana pasokan bahan bakar dan udara di satukan, sehinga dapat menghasilkan kualitas api yang di inginkan. Dari hasil penelitian yang dilakukan oleh nurda firmandika, 2011. Dengan bahan bakar yang digunakan yaitu bioetanol, jumlah lubang memiliki pengaruh terhadap nyala api. temperatur tertingi yaitu dengan jumlah lubang 20, diameter burner $9,5 \mathrm{~cm}$ dan diameter lubang $6 \mathrm{~mm}$ [1].

\section{KAJIAN PUSTAKA}

Berdasarkan hasil peneliti yang dilakukan oleh teguh santoso, 2010. tentang pengaruh ketingian tabung bahan bakar terhadap nyala api kompor bioetanol dari variasi jumlah lubang 12, 16, 20 dengan diameter tabung yang sama menemukan hasil ketinggian yang sama yaitu $100 \mathrm{~cm}$ [2].

Agus adhi saputro, 2011. Pengujian karakter pembakaran model burner diameter $26 \mathrm{~mm}$ dengan tinggi 5,5 mm, 9,5 $\mathrm{mm}$, dan $16 \mathrm{~mm}$ pada kompor methanol. Hasil penelitian diketahui bahwa tinggi burner berpengaruh terhadap karakteristik pembakaran kompor methanol [3].

Ardhi setyanto, 2011. Pengujian karakteristik pembakaran model burner dengan tinggi $17 \mathrm{~mm}$ dan diameter 21, 12,8, $10 \mathrm{~mm}$ pada kompor methanol. Hasil penelitian menunjukan bahwa variasi diameter berpengaruh terhadap karakteristik pembakaran yang dihasilkan oleh kompor methanol [4].

\section{Pembakaran}

Pembakaran merupakan suatu proses reaksi kimia antara suatu bahan bakar dan suatu oksidan, disertai juga dengan produksi panas yang kadang akan menimbulkan cahaya dalam bentuk api. Dalam suatu reaksi pembakaran lengkap suatu senyawa akan bereaksi dengan zat pengoksidasi dan produknya adalah merupakan senyawa dari tiap elemen dalam bahan bakar dengan zat pengoksidasi.

Kualitas dari pembakaran dapat ditingkatkan dengan sebuah desain alat pembakaran, seperti pembakar minyak dan mesin pembakaran dalam. Dalam perbaikan yang lebih lanjut dapat mencakup alat katalitik pasca pembakaran. Dalam sebuah proses derajat pembakaran dapat diukur dan dianalisis dengan peralatan uji.

2. Nyala Api

Sebuah nyala api umumnya merupakan sebuah campuran antara diffusion dan pre-mixed flame karena pada bagian tertentu nyala api tersebut, dimana udara dan bahan bakar akan tercampur dengan baik dan pada bagian lain akan tercampur secara tidak merata.

Dalam bidang teknik pembakaran terdiri dari berbagai macam jenis katagori nyala, jika di tinjau dari metode pencampuran reaktan nyala api digolongkan menjadi dua jenis yaitu nyala api premix dan nyala api difusi. Sedangkan nyala api premix (Premixed Flame) adalah nyala api yang dimana bahan bakar dan udara akan bercampur di dalam burner sebelum di alirkan pada nozzle dan akan mulai dibakar. Sedangkan nyala api difusi adalah nyala api yang dimana bahan bakar dan udara awalnya terpisah. Sehinga aliran bahan bakar yang keluar dari ujung nozzle akan bercampur dengan udara lingkungan secara difusi. 
Kestabilan nyala api dapat dinyatakan dari berbagai macam parameter antara lain :

a. Batas Mampu Nyala ( Limits of Flammability)

Batas Mampu Nyala yaitu antara kisaran batas bawah mampu nyala api dan batas atas mampu nyala atau lebih dikenal dengan istilah lower dan upper flammability limits.

b. Flashback

Ketika kecepatan pembakaran lebih cepat dari kecepatan udara dan bahan bakar maka akan terjadi flashback.

c. Lift-Off

Lift - off merupakan sebuah kondisi dimana nyala api terangkat, dimana nyala api tidak menyentuh permukaan mulut burner, namun api tetap stabil pada jarak tertentu dari burner

d. Blow-off

Blow - off merupakan sebuah kondisi dimana akibat dari batas kecepatan aliran bahan bakar lebih besar di bandingkan dengan kecepatan pembakaran sehinga api tidak menyala atau padam.

e. Lift-Up

Lift- up merupakan sebuah proses berpindahnya pangkal nyala api dari sebelumnya yang berada di ujung burner menuju benda penghalang.

3. Burner

Burner merupakan tempat terjadinya suatu pembakaran dalam kompor. Dimana bahan bakar dan oksigen bertemu burner sangat berpengaruh dalam pembentukan nyala api di dalam kontruksi kompor.

Jumlah lubang burner merupakan jumlah titik lubang yang berada di barner, dimana fungsi dari lubang barner adalah tempat keluarnya bahan bakar dan oksigen sehinga dapat terjadi pembakaran. Jumlah lubang di barner mempengaruhi kualitas nyala api dan jumlah bahan bakar. Semakin banyak lubang maka bahan bakar yang dihabiskan akan semakin banyak. Jumlah lubang pada burner juga sangat berkaitan dengan diameter burner, dimana semakin besar diameter burner maka jumlah lubang burner semakin banyak.

Diameter burrner sangat berpengaruh terhadap bahan bakar, karena semakin besar diameter burner maka api maka bahan bakar yang dibutuhkan untuk menghasilkan nyala api yang stabil harus banyak. Karena jika pasokan bahan bakar sedikit, maka api yang di hasilkan akan kecil. Diameter burner berpengaruh terhadap konsumsi bahan bakar, karena semakin besar diameter burner maka bahan bakar yang dihabiskan akan semakin banyak. Akan tetapi akan lebih cepat untuk memdidihkan air.

Berdasarkan dari jenis bahan bakar yang digunakan, burner diklasifikasikan menjadi tiga yaitu:
a. Burner untuk bahan- bakar cair
b. Burner untuk bakar bakar gas
c. Burner untuk bahan bakar padat

\section{METODE PENELITIAN}

Penelitian dilakukan pada instalasi penelitian seperti ditunjukan pada gambar.
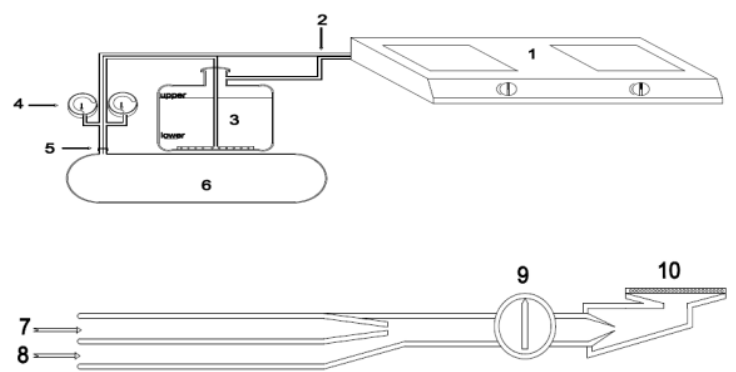

Gambar 1. Rangkaian kompor premium 
Keterangan:

1. Kompor LPG yg sudah di modifikasi

2. Selang kompresor dengan diameter dalam 5/16 inchi.

3. Tabung bahan bakar.

4. Flow meter.

5. Kran.

6. Tabung bertekanan ( kompresor).

7. Aliran bahan bakar.

8. Aliran udara.

9. Tombol menghidupkan kompor.

10. Burner pembakaran.

Dalam penelitinan ini data atau informasi yang dapat diperoleh melalui beberapa metode yaitu:

1. Penelitian kepustakaan (Studi Pustaka) Dalam penelitian ini penulis menggunakan buku-buku atau literature serta internet yang ada hubungannya dengan variasi jumlah lubang, diameter burner dan pemanfaatannya, baik sebagai sumber data dan informasi maupun sebagai teori dasar atau studi pustaka yang dapat dipertanggung jawabkan kebenaranya.

2. Exsperimen dan pengujian alat untuk mengetahui konsumsi bahan bakar, nyala api dan jumlah panas yang dihasilkan.

Variabel bebas dalam penelitian ini adalah memvariasikan diameter dan jumlah lubang burner dengan diameter $5 \mathrm{~cm}$ dan $6,5 \mathrm{~cm}$ dengan jumlah lubang 16,18 , dan 20 pada setiap burner. Dengan laju aliran 9 LPM untuk bahan bakar, dan 12 LPM untuk aliran udara.

Penelitian diawali dengan memasukan bahan bakar premium kedalam tabung bahan bakar dan tutup tabung bahan bakar serapat mungkin. Kemudian persiapkan flowmeter untuk di-stel aliran udaranya dengan cara menghidupkan kompresor dan membuka full kran yang sudah kita pasang di selang. kemudian setel flow meter, setelah di stel dengan laju aliran yang kita gunakan tutup kran yang ada di selang.

Kemudian kita buka kembali aliran udara yang berada di kompresor, dengan cara membuka sedikit kran. Setelah terlihat gelembung di tabung bahan bakar, kita berikan pematik api sehinga burner pada kompor menyala. Kemudian setelah menyala buka kran sepenuhnya sehinga aliran di flow meter terlihat menjadi seperti yang telah kita setel tadi.

Kemudian temperatur burner, suhu air, dan suhu air diukur dengan termocouple. Untuk gambar dari variasi burner yang dibuat dapat dilihat pada gambar di bawah ini.
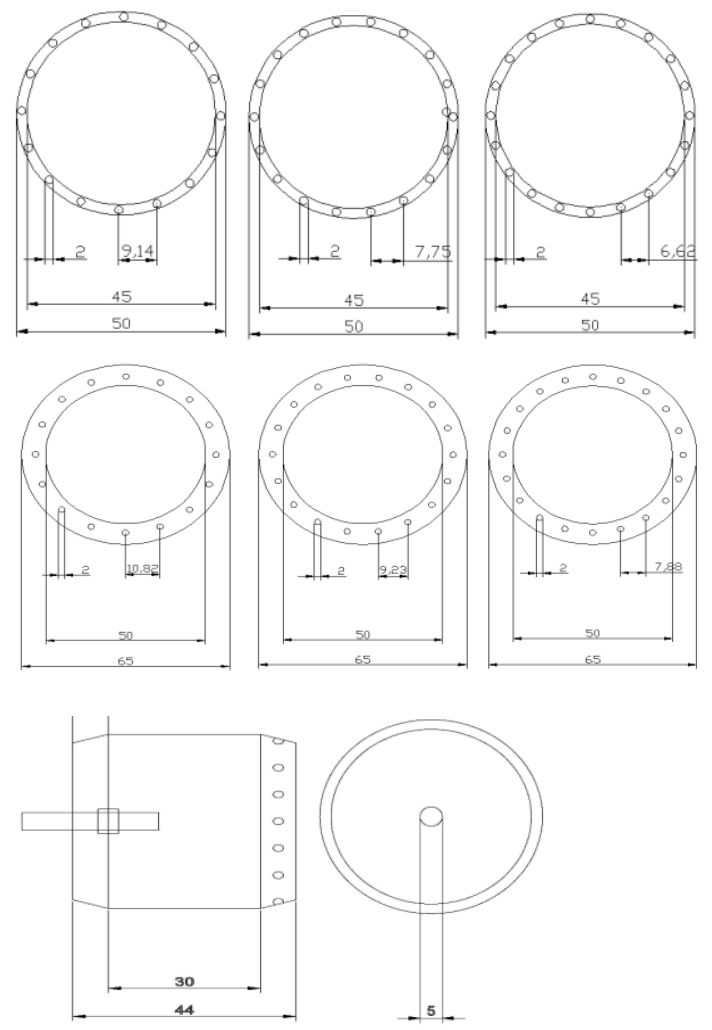

Gambar 2. Burner dan ukuranna 


\section{HASIL DAN PEMBAHASAN}

Data grafik diambil dari nilai rata rata hasil pengujian yang telah dilakukan, dan mendapatkan hasil sebagai berikut:

1. Suhu burner diameter $6,5 \mathrm{~cm}$ dengan suhu awal burner $33{ }^{\mathbf{0}} \mathrm{c}$.

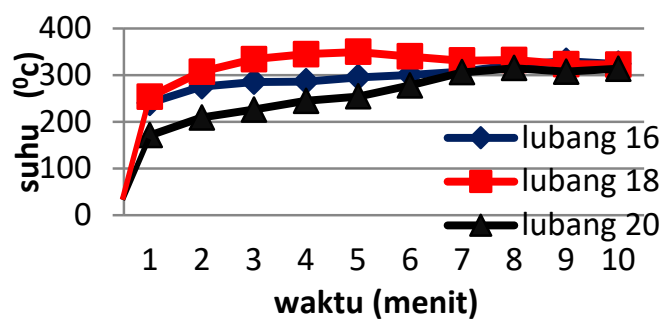

Gambar 3. Grafik suhu terhadap waktu pada burner diameter $6,5 \mathrm{~cm}$.

Dari hasil pengujian pengambilan data pada suhu burner diameter $6,5 \mathrm{~cm}$ dengan suhu awal $33{ }^{0} \mathrm{c}$ dengan waktu lama pengujian selama 10 menit dapat dilihat pada grafik, pada pengujian di burner 6,5 $\mathrm{cm}$ dengan pengujian pada jumlah lubang burner 16 memperoleh suhu tertingi 323,7 ${ }^{0} \mathrm{C}$ dan pengujian kedua dengan pada burner $6,5 \mathrm{~cm}$ dengan jumalah lubang 18 memperoleh suhu tertingi sebesar $322,3{ }^{\circ} \mathrm{C}$, dan pengujian yang ke tiga dilakukan dengan burner $6,5 \mathrm{~cm}$ mengunakan jumlah lubang 20 yang menghasilkan suhu tertingi $313,3{ }^{\circ} \mathrm{C}$.

2. Suhu api pada diameter burner 6,5 cm

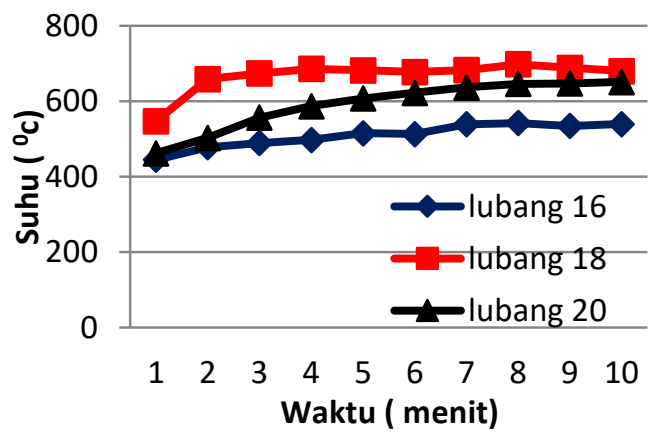

Gambar 4. Grafik suhu api terhadap waktu pada burner dengan diameter $6,5 \mathrm{~cm}$.
Dari hasil pengujian pengambilan data pada suhu api pada burner diameter 6,5 dan waktu lama pengujian selama 10 menit dapat dilihat pada grafik, pada pengujian pertama pada diameter burner $6,5 \mathrm{~cm}$ dengan pengujian pada jumlah lubang burner 16 memperoleh suhu tertingi 539,7 ${ }^{0} \mathrm{C}$, dan pengujian kedua pada diameter burner dengan jumalah lubang 18 memperoleh suhu tertingi sebesar $680{ }^{\circ} \mathrm{C}$, dan pengujian yang ke tiga dilakukanpada diamater $6,5 \mathrm{~cm}$ dengan mengunakan jumlah lubang 20 yang menghasilkan suhu tertingi $651,3{ }^{\circ} \mathrm{C}$.

\section{Suhu air pada penelitian burner 6,5} cm dengan suhu awal $29^{\circ} \mathrm{c}$

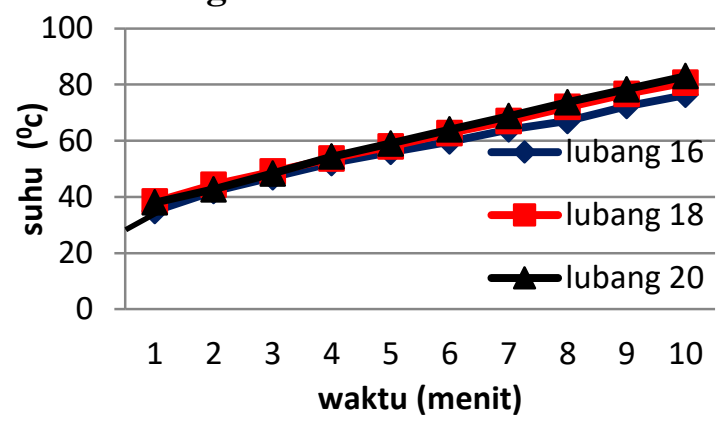

Gambar 5. Grafik suhu air terhadap waktu pada pengujian burner diameter $6,5 \mathrm{~cm}$.

Dari hasil pengujian pengambilan data pada suhu air pada pengujian burner diameter $6,5 \mathrm{~cm}$ dengan suhu awal $29{ }^{\circ} \mathrm{c}$ dan waktu lama pengujian selama 10 menit dapat dilihat pada table dan grafik, pada pengujian pertama dengan pengujian pada burner diameter $6,5 \mathrm{~cm}$ dengan jumlah lubang burner 16 memperoleh suhu tertingi $76,7^{\circ} \mathrm{C}$, dan pengujian kedua pada diameter $6,5 \mathrm{~cm}$ dengan jumalah lubang 18 memperoleh suhu tertingi sebesar $80,7{ }^{0} \mathrm{C}$, dan pengujian yang ke tiga dilakukan pada diameter $6,5 \mathrm{~cm}$ dengan mengunakan jumlah lubang 20 yang menghasilkan suhu tertingi $83{ }^{\circ} \mathrm{C}$. 
Jumlah panas yang diterima oleh air pada jumlah lubang 16 adalah:

$$
\begin{aligned}
Q= & m \times c_{p} \times\left(T_{1}-T_{0}\right) \\
Q= & 5 \mathrm{~kg} \times 4180 \frac{\mathrm{kJ}}{\mathrm{kg}{ }^{\circ} \mathrm{c}} \times\left(76.7^{\circ} \mathrm{C}-\right. \\
& \left.29^{\circ} \mathrm{C}\right) \text { maka } Q=996,9 \mathrm{~kJ}
\end{aligned}
$$

Jumlah panas yang diterima oleh air pada jumlah lubang 18 adalah:

$Q=m x c_{p} x\left(T_{1}-T_{0}\right)$

$$
\begin{aligned}
Q= & 5 \mathrm{~kg} x 4180 \frac{\mathrm{kJ}}{\mathrm{kg} . \mathrm{C}} x\left(80,7{ }^{\circ} \mathrm{C}-\right. \\
& \left.29^{\circ} \mathrm{C}\right) \text { maka } Q=1080,5 \mathrm{~kJ}
\end{aligned}
$$

Jumlah panas yang diterima oleh air pada jumlah lubang 20 adalah:

$$
\begin{aligned}
Q= & m \times c_{p} x\left(T_{1}-T_{0}\right) \\
Q= & 5 \mathrm{~kg} \times 4180 \frac{\mathrm{kJ}}{\mathrm{kg} \cdot{ }^{\circ} \mathrm{c}} x\left(83{ }^{\circ} \mathrm{C}-\right. \\
& \left.29{ }^{\circ} \mathrm{C}\right) \text { maka } Q=1128,6 \mathrm{~kJ}
\end{aligned}
$$

\section{Suhu burner diameter $5 \mathrm{~cm}$ dengan suhu awal burner $33^{\circ} \mathrm{c}$.}

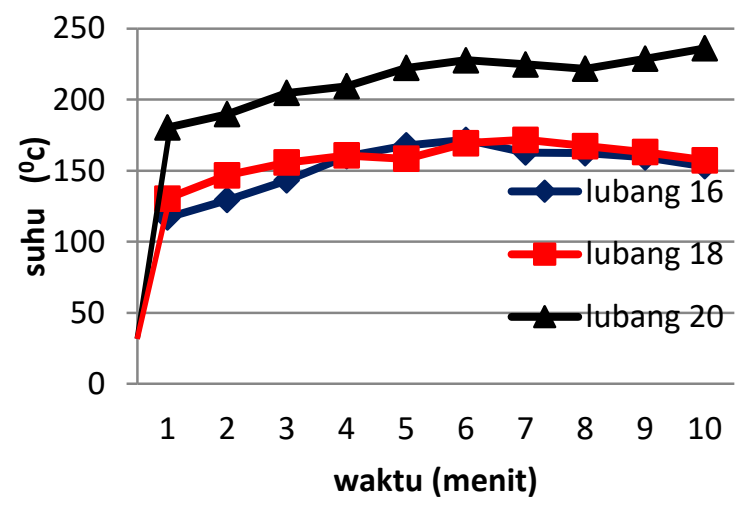

Gambar 6. Grafik suhu tyerhadap waktu pada burner diameter $5 \mathrm{~cm}$.

Dari hasil pengujian pengambilan data pada suhu burner diameter $5 \mathrm{~cm}$ dengan suhu awal $33{ }^{\circ} \mathrm{c}$ dan waktu lama pengujian selama 10 menit dapat dilihat pada table dan grafik, pada pengujian pertama dengan pengujian pada jumlah lubang burner 16 memperoleh suhu tertingi $153{ }^{0} \mathrm{C}$, dan pengujian kedua dengan jumalah lubang 18 memperoleh suhu tertingi sebesar $157,3{ }^{\circ} \mathrm{C}$, dan pengujian yang ke tiga dilakukan dengan mengunakan jumlah lubang 20 yang menghasilkan suhu tertingi $236{ }^{\circ} \mathrm{C}$

\section{Suhu api pada diameter burner $5 \mathrm{~cm}$}

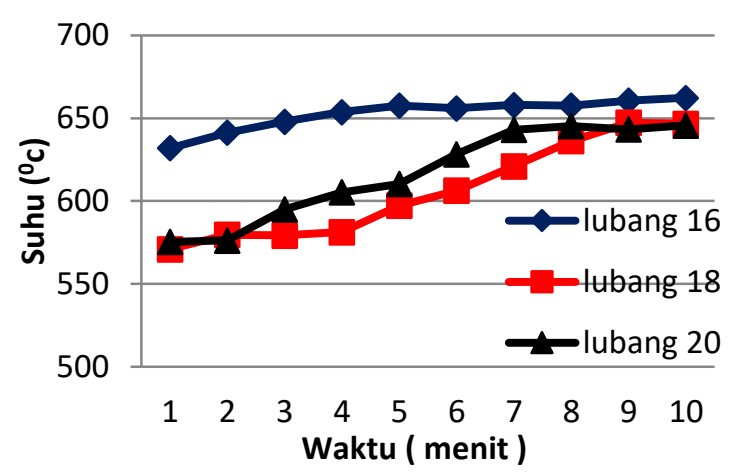

Gambar 7. Grafik suhu api terhadap waktu pada burner berdiameter $5 \mathrm{~cm}$.

Dari hasil pengujian pengambilan data pada suhu api pada burner diameter 5 dan waktu lama pengujian selama 10 menit dapat dilihat pada table dan grafik, pada pengujian pertama dengan pengujian pada jumlah lubang burner 16 memperoleh suhu tertingi $646,7{ }^{0} \mathrm{C}$, dan pengujian kedua dengan jumalah lubang 18 memperoleh suhu tertingi sebesar $662,3{ }^{0} \mathrm{C}$, dan pengujian yang ke tiga dilakukan dengan mengunakan jumlah lubang 20 yang menghasilkan suhu tertingi $645,7{ }^{\circ} \mathrm{C}$

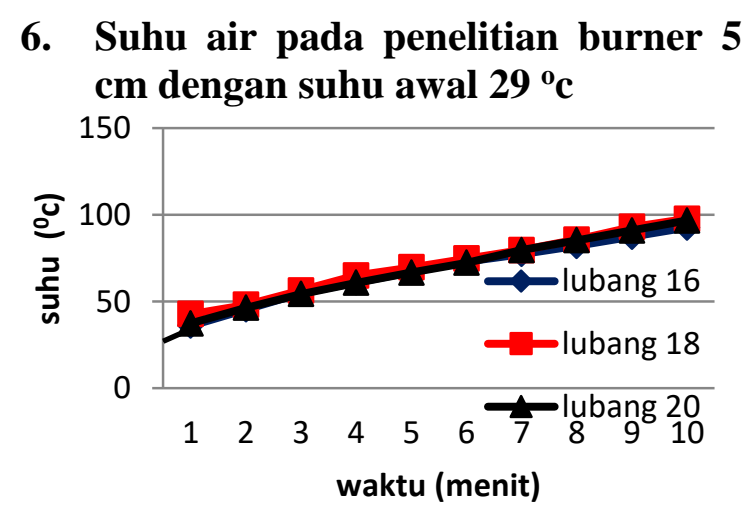

Gambar 8. Grafik suhu air terhadap waktu pada pengujian burner berdiameter $5 \mathrm{~cm}$.

Dari hasil pengujian pengambilan data pada suhu air pada pengujian burner diameter $5 \mathrm{~cm}$ dengan suhu awal $29^{\circ} \mathrm{c}$ dan waktu lama pengujian selama 10 menit 
dapat dilihat pada table dan grafik, pada pengujian pertama dengan pengujian pada jumlah lubang burner 16 memperoleh suhu tertingi $92,7{ }^{0} \mathrm{C}$, dan pengujian kedua dengan jumalah lubang 18 memperoleh suhu tertingi sebesar $97,7{ }^{\circ} \mathrm{C}$, dan pengujian yang ke tiga dilakukan dengan mengunakan jumlah lubang 20 yang menghasilkan suhu tertingi $96,7{ }^{\circ} \mathrm{C}$.

Jumlah panas yang diterima oleh air pada jumlah lubang 16 adalah:

$$
\begin{aligned}
Q= & m \times c_{p} \times\left(T_{1}-T_{0}\right) \\
Q= & 5 \mathrm{~kg} \times 4180 \frac{\mathrm{kJ}}{\mathrm{kg}^{\circ} \mathrm{c}} \times\left(92,7^{0} \mathrm{C}-\right. \\
& \left.29^{\circ} \mathrm{C}\right) \text { maka } Q=1.331,3 \mathrm{~kJ}
\end{aligned}
$$

Jumlah panas yang diterima oleh air pada jumlah lubang 18 adalah:

$$
\begin{aligned}
Q= & m x c_{p} x\left(T_{1}-T_{0}\right) \\
Q= & 5 \mathrm{~kg} x 4180 \frac{\mathrm{kJ}}{\mathrm{kg} . \mathrm{c}} \times\left(97,7^{\circ} \mathrm{C}-\right. \\
& \left.29^{\circ} \mathrm{C}\right) \text { maka } Q=1.435,8 \mathrm{~kJ}
\end{aligned}
$$

Jumlah panas yang diterima oleh air pada jumlah lubang 20 adalah:

$$
\begin{aligned}
Q= & m \times c_{p} \times\left(T_{1}-T_{0}\right) \\
Q= & 5 \mathrm{~kg} \times 4180 \frac{\mathrm{kJ}}{\mathrm{kg}{ }^{\circ} \mathrm{C}} \times\left(96,7{ }^{0} \mathrm{C}-\right. \\
& \left.29{ }^{0} \mathrm{C}\right) \text { maka } Q=1.414,9 \mathrm{~kJ}
\end{aligned}
$$

\section{Jumlah lubang}

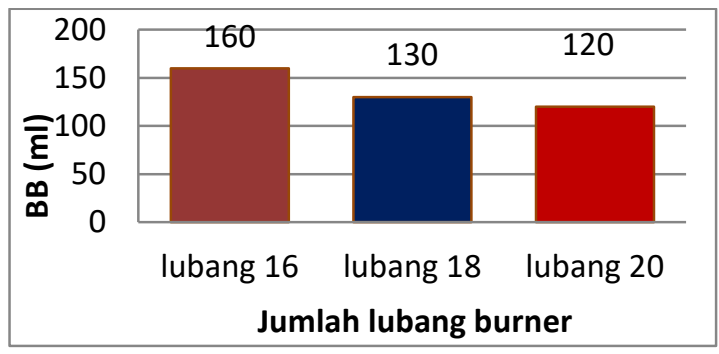

Gambar 9. Grafik pengaruh jumlah lubang terhadap jumlah bahan bakar

Pada gambar 9. diatas dapat disimpulkan bahwa pada jumlah jumlah lubang 16 merupakan yang paling banyak menghabiskan bahan bakar bakar sebanyak
$160 \mathrm{ml}$. Karena dengan lebih sedikitnya jumlah lubang barner, dengan aliran bahan bakar yang selalu mengalir maka bahan bakar akan terdorong keluar dari burner lebih kuat dari lubang burner. Sehinga pembakaran yang dihasilkan lebih luas dan menyebabkan bahan bakar lebih boros.

\section{Diameter burner}

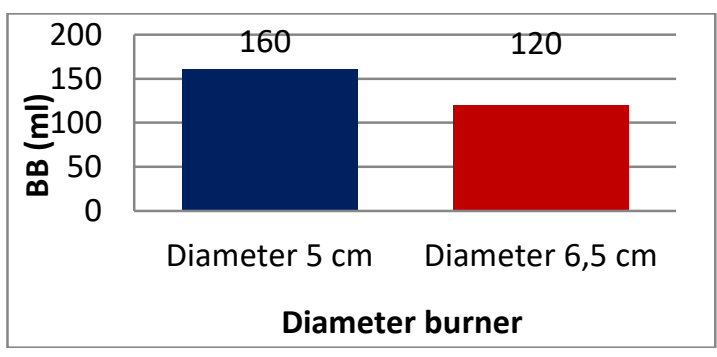

Gambar 10. Grafik pengaruh diameter terhadap jumlah bahan bakar.

Pada gambar 10, diatas dapat disimpulkan bahwa pada diameter burner 5 $\mathrm{cm}$ merupakan yang paling banyak menghabiskan bahan bakar yaitu sebanyak $160 \mathrm{ml}$. Karena dengan lebih kecilnya diameter burner, aliran bahan bakar yang mengisi burner lebih sedikit dan akan langsung keluar dari lubang burner sehinga bakar akan terdorong keluar dari burner lebih kuat sehinga pembakaran yang dihasilkan lebih luas sehinga menyebabkan bahan bakar lebih boros.

\section{Pengaruh variasi jumlah lubang dan diameter burner terhadap nyala api dan jumlah panas yang dihasilkan.}

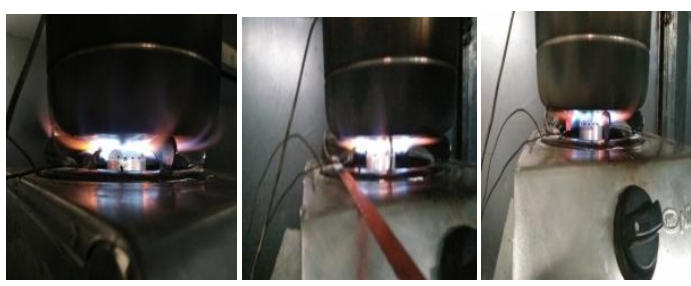

Gambar 11. Nayala api pada dengan jumlah lubang 16, 18, 20 pada burner diameter $5 \mathrm{~cm}$. 
Pada gambar 11. diatas dapat disimpulkan bahwa pada setiap jumlah lubang burner memiliki nyala warna api yang sama, namun dapat dilihat perbedaanya dari besarnya nyala api. Jumlah lubang burner yang lebih sedikit memiliki nyala api yang lebih besar, karena aliran bahan bakar terdorang keluar lebih kuat melalui jumlah lubang burner.

\section{Diameter burner}
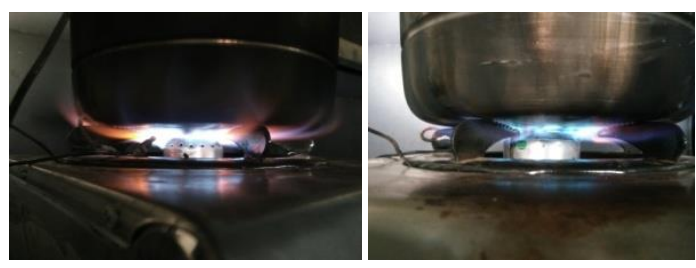

Gambar 12. Gambar nyala api pada diameter burner 5 dan $6,5 \mathrm{~cm}$

Pada gambar 12. diatas dapat disimpulkan bahwa pada setiap diameter burner memiliki nyala warna api yang sama, namun dapat dilihat perbedaan dari besarnya nyala api. Jumlah diameter burner yang lebih kecil miliki nyala api yang lebih besar, dikarenakan aliran bahan bakar dari nozel yang masuk ke burner menjadi lebih cepat keluar dari burner.

\section{Pengaruh jumlah lubang terhadap jumlah panas yang diterima oleh air}

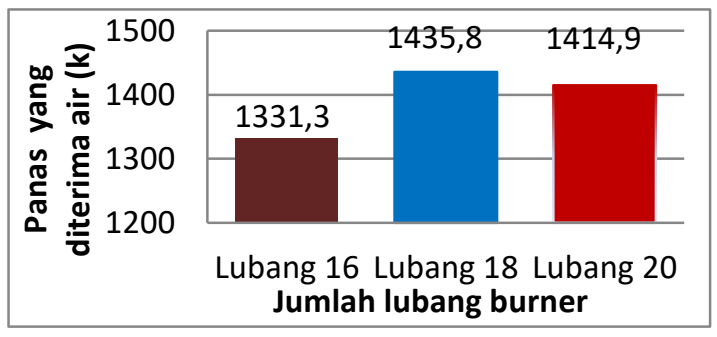

Gambar 13. Pengaruh jumlah lubang terhadap jumlah panas yang diterima oleh air

Pada gambar 13. diatas dapat disimpulkan bahwa lubang burner 18 memiliki kenaikan jumlah panas yang dihasilkan oleh air terbesar yaitu 1435,8 kJ. Dikarenakan semakin sedikit jumlah lubang burner maka aliran bahan bakar yang keluar dari burner semakin kuat mengakibatkan nyala api yang besar, dan pada jumlah lubang 18 merupakan jumlah lubang terbaik untuk burner berdiameter 5 $\mathrm{cm}$. Namun pada jumlah lubang 20 jumlah suhu yang dihasilkan menurun, dikarenakan aliran uap bahan bakar semakin menurun dikarenakan lubang keluar bahan bakar semakin banyak sehinga mengakibatkan penurunan jangkauan api.

\section{Pengaruh jumlah lubang terhadap jumlah panas yang diterima oleh air}

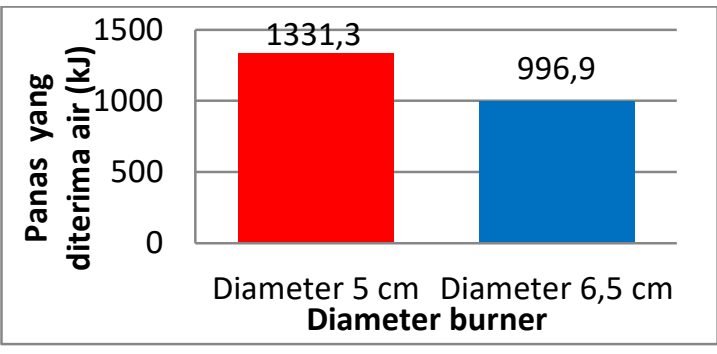

Gambar 14. Pengaruh diameter burner terhadap jumlah panas yang di terima oleh air

Pada gambar 14. diatas dapat disimpulkan bahwa pada burner dengan diameter $5 \mathrm{~cm}$ dengan jumlah lubang 16 memiliki jumlah panas yang diterima oleh air lebih besar yaitu 1331,3 kJ. Dikarenakan diameter burner yang lebih kecil memiliki aliran bahan bakar yang lebih kuat sehinga nyala api yang dihasilkan lebih besar dan luas.

\section{KESIMPULAN}

Dari hasil pengujian yang telah dilakukan dapat disimpulkan: 
1. Pada diameter $5 \mathrm{~cm}$ dengan jumlah lubang 16 menghabiskan bahan bakar sebanyak $160 \mathrm{ml}$, dan pada burner 6,5 dengan jumlah lubang 16 menghabiskan bahan bakar sebanyak $120 \mathrm{ml}$ yang dilakukan pada penelitian selama 10 menit.

2. Pada setiap jumlah lubang burner memiliki nyala warna api yang sama, namun dapat dilihat perbedaanya dari besarnya nyala api. Sehinga pada diameter $5 \mathrm{~cm}$ dengan jumlah lubang 18 memiliki jumlah panas tertinggi yaitu sebesar 1435,8 kJ

\section{DAFTAR PUSTAKA}

[1] Firmandika, Nurda. 2011. Rencang Bangun Burner Kompor Methanol Dengan Variasi Jumlah Lubang 16, 20, 22 Diameter Lubang $6 \mathrm{~mm}$ Diameter Burner 9,5 cm. Teknik Mesin Fakultas Teknik Universitas Muhammadiyah Surakarta.

[2] Santoso, Teguh. 2010. Pengaruh Variasi Jumlah Lubang Burner Terhadap Kalori Pembakaran Yang Dihasilkan Pada Kompor Methanol Dengan Variasi Jumlah Lubang 12, 16, 20. Tugas Akhir Teknik Mesin.

[3] Saputro, A.A. 2011. Pengujian Karakteristik Pembakaran Model Burner Diameter $26 \mathrm{~mm}$ Dengan Tinggi 5,5 mm, 9,5 mm, Dan $16 \mathrm{~mm}$ Pada Kompor Methanol. Tugas Akhir Jurusan Teknik Mesin Universitas Muhamadiyah Surakarta.
[4] Setianto, Ardi. 2011. Pengujian Karakteristik Pembakaran Model Burner Dengan Tinggi 17 mm Dan Diameter 21, 12,8, 10 mm Pada Kompor Methanol. Tugas Akhir Jurusan Teknik Mesin Unifersitas Muhammadiyah Surakarta.

[5] Budiyanto, Wakit. 2009. Unjuk Kerja Kompor Etanol Kadar Rendah. Jurusan Teknik Mesin Fakultas Teknik Unifersitas Sebelas Maret Surakarta.

[6] Djokosetyardjo,M,J.1993. Katel Uap. Jakarta Pradnya Paramita.

[7] Sriwahyu. 2012. Variasi Jumlah Lubang Burner 14, 18, Dan 22 Dengan Diameter $5 \mathrm{Mm}$ Pada Kompor Methanol Terhadap Karakteristik Pembakaran. Tugas akhir jurusan teknik mesin universitas muhammadiyah surakarta 2012.

[8] Wibowo, andi. 2011. Pengujian Karakteristik Pembakaran Model Burner Dengan Diameter $26 \mathrm{Mm}$ Dengan Jumlah Lubang 8, 11 Dan 16 Pada Kompor Methanol. Jurusan Teknik Mesin Fakultas Teknik Universitas Muhammadiyah Surakarta. 